The correlation between $\mathrm{PaO}_{2}$ and serum concentrations of testosterone, FSH, thyroid hormones, and hormone binding globulins suggests a causal association. Normal basal LH and FSH concentrations and normal pituitary responses to injected GnRH in this case and patients with respiratory disease ${ }^{3}$ suggest hypothalamic suppression, though additional hypoxic testicular suppression seems possible. While thyroid hormone values tended to increase with improved $\mathrm{PaO}_{2}$ the rise was less than with testosterone, and in respiratory disease also the hypothalamopituitary-testicular axis seems to be particularly sensitive to hypoxia. Absent TSH responses to injected TRH before weight reduction and their return to normal after diet along with a rise in serum thyroxine concentration suggested reversible pituitary suppression of TSH even though serum thyroxine values were normal throughout. These normal values were also found in occasional instances in our patients with respiratory disease ${ }^{3}$ in the presence of pituitary suppression of TSH.

1 Semple Pd'A, Beastall GH, Watson WS, Hume R. Serum testosterone depression associated with hypoxia in respiratory failure. Clin Sci 1980;58:105-6.

emple Pd'A, Beastall GH, Hume R. Male sexual dysfunction, low serum testosterone and respiratory hypoxia. British fournal of Sexual Medicine 1980;64:48, 3 Semple Pd'A, Beastall GH, Brown TM, Stirling KW, Mills RJ, Watson WS. Sex hormone suppression and sexual impotence in hypoxic pulmonary fibrosis. Thorax $1984 ; 39: 46-51$.

4 Semple Pd'A, Watson WS, Beastall GH, Hume R. Endocrine and metabolic studies in unstable cor pulmonale. Thorax 1983;38:45-9. 5 Guilleminault C, Dement WC. Sleep apnoea syndromes. New York: Alan R Liss,

(Accepted 11 fuly 1984)

Chest Unit, Inverclyde Royal Hospital, Greenock PA16 OXN

PETER D'A SEMPLE, MB, MRCP, consultant physician

ALASTAIR GRAHAM, $M B$, registrar in medicine

YVONNE MALCOLM, SRD, dietitian

Department of Clinical Biochemistry, Royal Infirmary, Glasgow G4 GRAHAM H BEASTALL, PHD, top grade biochemist

Department of Clinical Physics and Bioengineering, Southern General Hospital, Glasgow G51

WALTER S WATSON, PHD, principal physicist

Correspondence to: Dr P d'A Semple.

\section{Fixed drug eruption masquerading as herpes simplex labialis}

Drug eruptions are common, but the true incidence is unknown as many are not reported. Fixed drug eruptions are less common and may not be recognised. We report a case that was misdiagnosed as herpes simplex labialis.

\section{Case report}

A 38 year old woman took Equagesic tablets (aspirin, meprobamate, and ethoheptazine) intermittently for pain in her leg. She developed an erythematous lesion on the left lateral margin of the lower lip and surrounding skin (figure), which became vesicular and resolved after 10 days leaving faint pigmentation. It recurred one month later, and herpes simplex labialis was diagnosed. During the next six months the lesion recurred five times and was eventually accompanied by similar lesions on the dorsum of her hand, thigh, and abdomen. A challenge test to Equagesic and to meprobamate caused a recurrence of the lesions. There was no recurrence after Equagesic was stopped.

\section{Comment}

Fixed drug eruptions characteristically recur at the same sites whenever the offending agent is given. Initially the lesion is erythematous, mildly oedematous, and sometimes vesicular. Afte- seven to 10 days it becomes a dusky violaceous colour, and after repeated attacks the pigmentation may become permanent. Eruptions often occur on the palms and soles but may affect the glans penis and mucous membranes, and the condition comes into the differential diagnosis of oral and genital herpes.

The pathogenesis is unknown, but during the acute phase of the eruption a factor was identified in the serum of 21 affected patients that induced lymphocyte transformation. ${ }^{2}$ Skin transplanted from an affected site to a non-affected site loses its capacity to react, while normal skin transplanted to an affected site becomes reactive. ${ }^{3}$

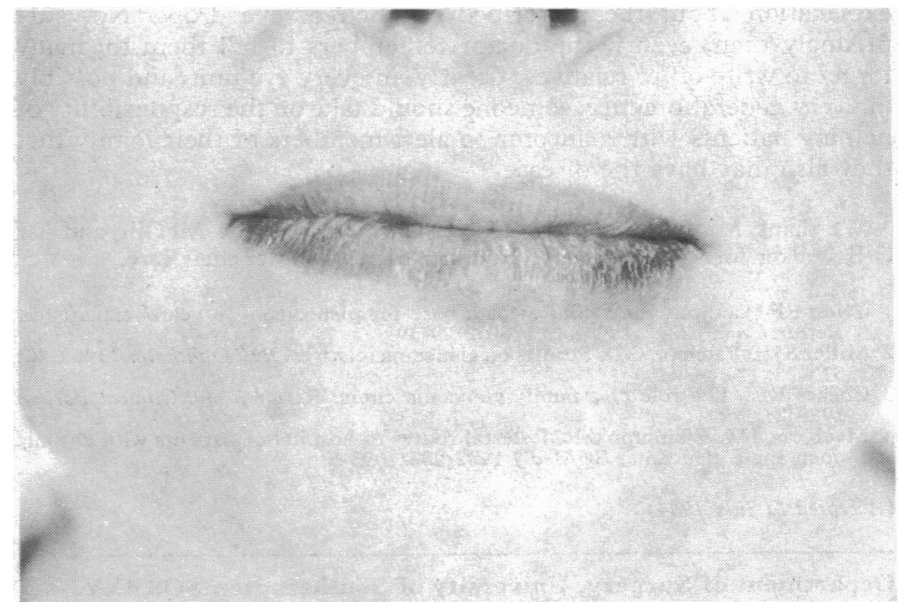

Fixed eruption on left lateral margin of lower lip caused by ingestion of Equagesic.

Fixed drug eruption should be considered when lesions recur at the same site. The drugs associated with fixed drug eruption are as follows:

\section{Commonly implicated}

Barbiturates

Phenolphthalein

Sulphonamides

Phenylbutazone

Sulphonamides
Tetracyclines

Less commonly implicated

Acetarsol

Acriflavine

Amidopyrine

Amoxycillin

Ampicillin

Amylobarbitone

Arsenicals

Aspirin

Atropine

Bisacodyl

Buthalitone

Butobarbitone

Carbromal

Chloral hydrate

Chlordiazepoxide

Chlormezanone

Chlorphenesin carbamate

Codeine

Co-trimoxazole

Cyclizine

Dapsone

Dimethylchlortetracycline

Diphenhydramine

Dipyrone

Disulfiram

Emetine

Erythromycin

Glutethimide

Griseofulvin
Hydroxyurea

Isoaminile citrate

Meprobamate

Methaqualone

Metronidazole

Minocycline

Nystatin

Oxyphenbutazone

Paracetamol

Penicillins

Phenacetin

Phenazone

Phenobarbitone

Phthalylsulphathiazole

Quinine

Salicylates

Succinylsulphathiazole

Sulphadiazine

Sulphadimethoxine

Sulphadimidine

Sulphamerazine

Sulphamethoxazole

Sulphamethoxydiazine

Sulphamethoxypyridazine

Sulphaphenazole

Sulphathiazole

Sulphobromophthalein

Trimethoprim
1 Baker H. In: Rook A, Wilkinson DS, Ebling FJG, eds. Textbook of derma ology. 3rd ed. Oxford: Black:well Scientific Publications, 1979:1121-2.

2 Gimmez-Camarasa JM. Lymphocyte transformation test in fixed drug eruption. $N$ Engl $₹$ Med 1975;292:819-21.

3 Bruinsma W. A guide to drug eruptions. 3rd ed. Oosthuizen, Netherlands: De Zwaluw, 1982:63-7.

(Accepted 17 fuly 1984)

Bristol Royal Infirmary, Bristol BS2 8HW

J BOYLE, MB, MRCP, senior registrar, department of dermatology

B MOUL, MPS, staff pharmacist, regional drug information centre

Correspondence to: Dr J Boyle. 